\title{
Y Tizoma \\ Os visíveis e invisíveis na fotografia de Julia Kater
}

Grécia Falcão'

Resumo: A partir das colagens fotográficas da artista francopaulistana Julia Kater, este artigo traça relações entre o campo de estudo da estética e da comunicação para abordar uma teoria visual que compreende as imagens para além dos critérios da representação. Em outras palavras, busco ultrapassar o entendimento da fotografia como mero objeto que captura aparências - e registra de forma fiel a realidade - para compreender a imagem-técnica por meio de suas capacidades de ordenar e reordenar nossas maneiras de perceber o mundo. Vale dizer que esta abordagem teórica irá se situar sob a análise de fotografias que, no campo da arte contemporânea, trabalham a subtração dos elementos visuais; a tal ponto que a negação visual que percorre as obras de Julia Kater nos levará a encarar a fotografia - imagem-técnica historicamente atribuída ao "fazer ver" - como visibilidade cujo significado opera mediante a constante tensão entre o "ver" e "não-ver".

Palavraschave: Fotografia. Arte Contemporânea. Teoria da imagem.

\section{Los visibles e invisibles en la fotografía de Julia Kater}

Resumen: A partir de los collages fotográficos de la artista francopaulistana Julia Kater, este artículo traza relaciones entre el campo de estudio de la estética y de la comunicación para abordar una teoría visual que comprende las imágenes más allá de los criterios de la representación. En otras palabras, busco sobrepasar el entendimiento de la fotografía como mero objeto que captura apariencias - y registra fielmente la realidad - para comprender la imagen técnica por medio de sus capacidades de ordenar y reordenar nuestras maneras de percibir el mundo. Vale decir que este enfoque teórico se situará bajo el análisis de fotografías que, en el campo del arte contemporáneo, trabajan la sustracción de los elementos visuales; a tal punto que la negación visual que recorre las obras de Julia Kater nos llevará a encarar la fotografía-imagen-técnica históricamente atribuida al "hacer ver" - como visibilidad cuyo significado opera mediante la

${ }^{1}$ Mestre e Doutora em Tecnologias da Comunicação e Cultura (UERJ). E-mail: gre.falcao@gmail.com 
constante tensión entre el "ver" y "no- ver ".

Palabras clave: Fotografía. Arte Contemporaneo. Teoría de la imagen.

\title{
The visible and invisible in Julia Kater's photograph
}

\begin{abstract}
From the photographic collages of the french-brazilian artist Julia Kater, this article traces relations between the field of study of aesthetics and communication to approach a visual theory that understands images beyond the criteria of representation. In other words, I seek to go beyond the understanding of photography as a mere object that captures appearances - and faithfully records the reality - to understand the technical image through its capacities to order and reorder our ways of perceiving the world. It is worth to say that this theoretical approach will be situated under the analysis of photographs that, in the field of contemporary art, work the subtraction of the visual elements; so much so that the visual negation that runs through the works of Julia Kater will lead us to face the photograph - technical image historically attributed to "seeing"- as a visibility whose meaning operates through the constant tension between "seeing" and "non-seeing".
\end{abstract}

Keywords: Photography. Contemporary art. Image theory.

\section{Introdução}

A partir das colagens fotográficas da artista franco-paulistana Julia Kater, este artigo traça relações entre o campo de estudo da estética e da comunicação para abordar uma teoria visual que compreende as imagens para além dos critérios da representação. Em outras palavras, busco ultrapassar o entendimento da fotografia como mero objeto que captura aparências - e registra de forma fiel a realidade - para compreender a imagem-técnica por meio de suas capacidades de ordenar e reordenar nossas maneiras de perceber o mundo.

Vale dizer que esta abordagem teórica irá se situar sob a análise de fotografias que, na arte contemporânea, trabalham a subtração dos elementos visuais; a tal ponto que a negação visual que percorre as obras de Julia Kater nos levará a encarar a fotografia - imagemtécnica historicamente atribuída ao "fazer ver" - como visibilidade cujo significado opera mediante a constante tensão entre o "ver" e "não-ver".

O pensamento do filósofo Maurice Merleau-Ponty será, por sua vez, outro auxílio contundente para compreender a apreensão estética para além da interpretação do objeto artístico - critérios de autoria, vanguarda e estilo - que possam limitar os usos e 


\section{Rizoma}

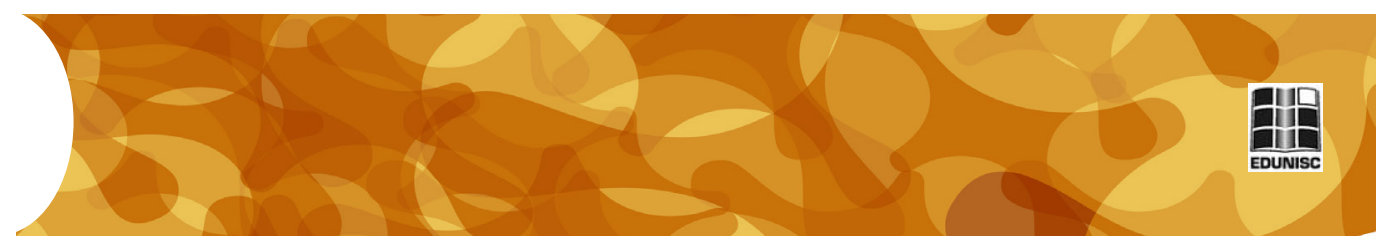

funções do próprio meio fotográfico e sua forma visual. Para tanto, nos parece pertinente citar uma epistemologia que busque ampliar o significado das imagens fotográficas, levando em conta, principalmente, certa oposição entre "visível" e "invisível" que o filósofo começa a explorar sobretudo no âmbito da experiência pictórica. Trata-se de uma reflexão ontológica sobre a pintura que, aqui, diante da obra da artista visual Julia Kater, buscaremos estender ao meio fotográfico.

\section{O elogio ao desencontro do ver}

Na série "Lugar do Outro" (2014), Julia Kater propõe um novo sentido visual diante de "rasgos" que urgem propositalmente em suas imagens fotográficas (Figura 1 e Figura 2). Estas lacunas visuais fabricam desenhos que ora parecem deformar o registro fotográfico original, ora criar nova relação entre figura e fundo na fotografia de paisagem. Em outras palavras, ao invés de significar "a falta", "a nulidade" ou "a ausência", a subtração dos elementos visíveis na obra de Kater parece promover novos contornos à visão. Tornam-se presença.

Figura 1 - Série "Lugar do Outro" (2014)

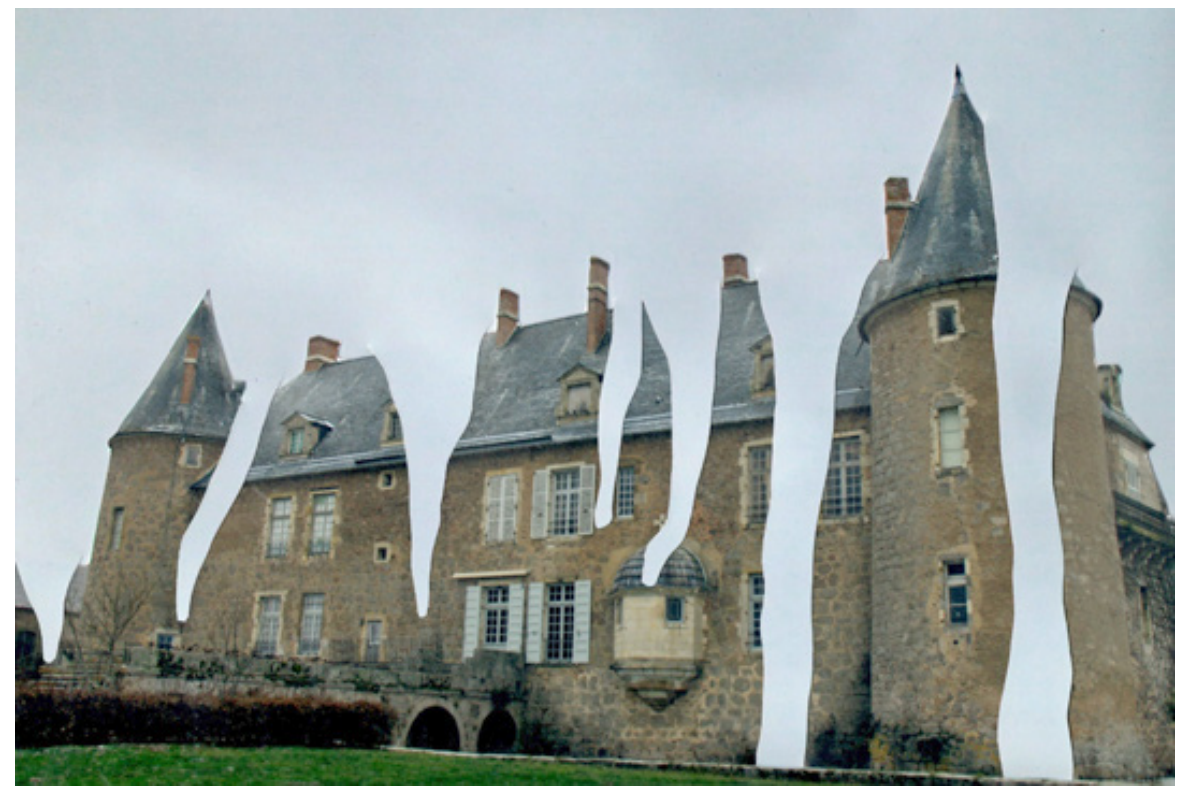

Fonte: reprodução imagem Julia Kater 


\section{$\gamma_{\text {Rizoma }}$}

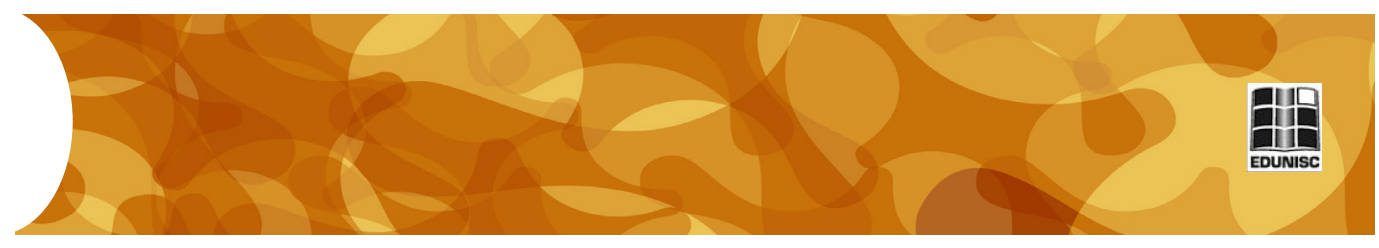

Figura 2 - Série "Lugar do Outro" (2014)

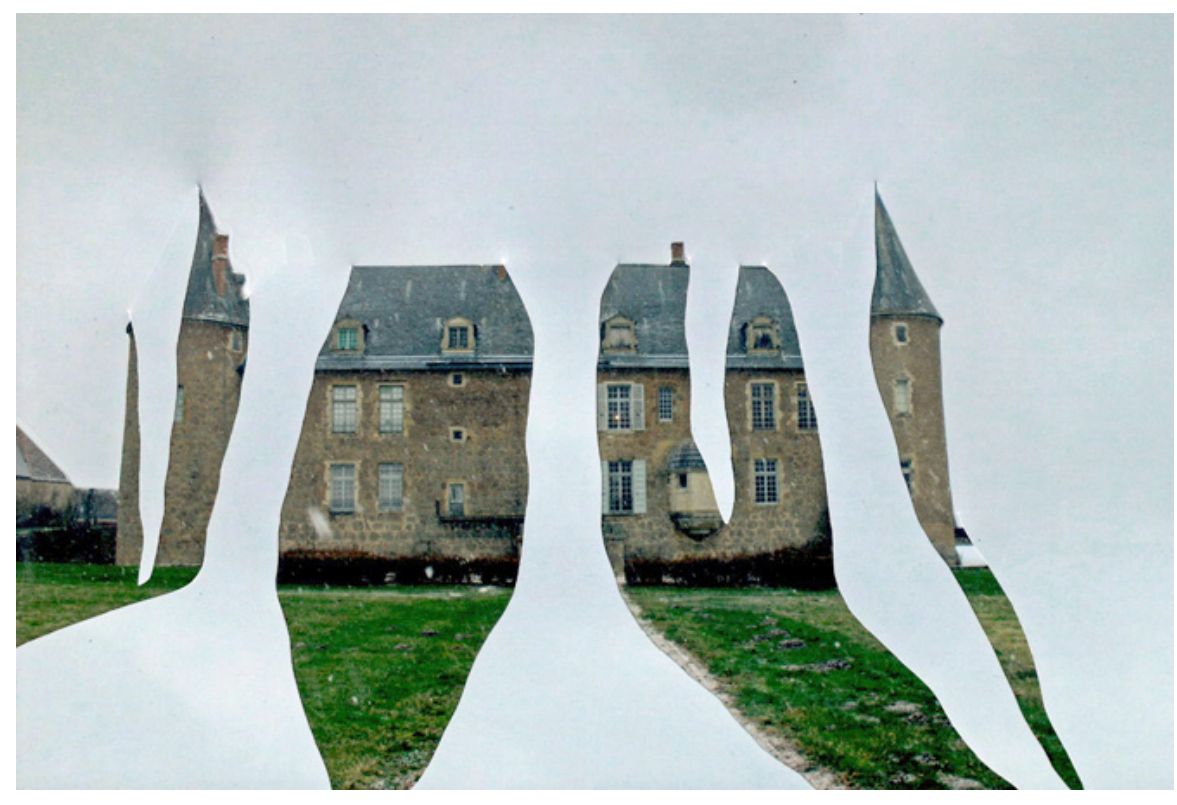

Fonte: reprodução imagem Julia Kater

Este "pontapé" inicial pela obra de Julia Kater nos servirá, por sua vez, como alegoria para desdobramentos teóricos que visam a ampliar as possibilidades narrativas da técnica fotográfica. No lugar de certas fotografias que buscam a apreensão visual clara, nítida e objetiva, estas imagens fotográficas apresentam apagamentos feitos propositalmente pela artista. São barreiras visuais que põem em tensão o caráter representativo da técnica fotográfica e visam a desestabilizar os lugares de reconhecimento da imagem, onde categorias como verdade e ficção estão associadas respectivamente ao binômio visível-invisível.

Desde o Renascimento no século (XIV-XVI), a arte formalizase enquanto disciplina histórica e reflete sua intensa busca acadêmica pela mimese - pela semelhança - o efeito-real da representação por imagens. A pintura renascentista visa a retratar objetos, pessoas e "cenas" com cada vez mais detalhes e precisão, vide os pintores clássicos e suas incansáveis tentativas de organizar o espaço pictórico sob um olhar perspectivado, que construía a aparência do mundo utilizando espelhos, lentes, projeções óticas e cálculos. Trata-se de uma criação de pinturas que preza pela "matematização" das formas visuais; um saber-fazer onde a imagem fotográfica - em sua transparência técnica (sem a suposta interferência da mão do pintor) - parecia facilitar o decalque e transposição "calculada" do mundo sob a superfície plana do filme fotográfico. Não à toa, nos idos de seu surgimento, o registro fotográfico é utilizado pela ciência moderna como fonte de observação e controle das evidências, tornando a 

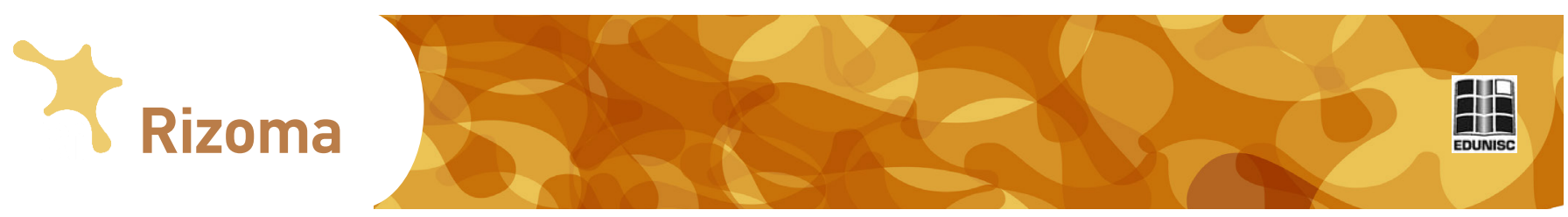

imagem fotográfica uma ferramenta indispensável para representar a natureza e explicar seus fenômenos.

Consequentemente, ao passo que se tornava comum associar a técnica fotográfica à captura fiel da realidade - numa construção de saberes mediado por imagens - não podemos nos furtar de questionar os atuais "modos de ver"; tendo em vista que o olhar é fruto de uma elaboração social em meio a problemáticas históricas, culturais, políticas e, por que não, técnicas. Não obstante, tratamos aqui de uma subjetividade marcada indubitavelmente por tal modo tecnológico de criar e de representar o mundo, um pensamento que alude à filosofia de Gilbert Simondon (1958): autor que prescreve como os objetos técnicos operam não só diante da dimensão material do mundo, mas também afetam as maneiras de agir, de ser e de perceber do sujeito.

Mas o que nos fala tal fenômeno da arte, a exemplo das obras de Julia Kater, onde os planos fotográficos subtraem diversos elementos que previamente o definiam? São imagens que, aparentemente, visam a escapar desta tradição que liga a fotografia à ordem visual realista (Figura 3).

Figura 3 - Untitled, At de same time series (2012)

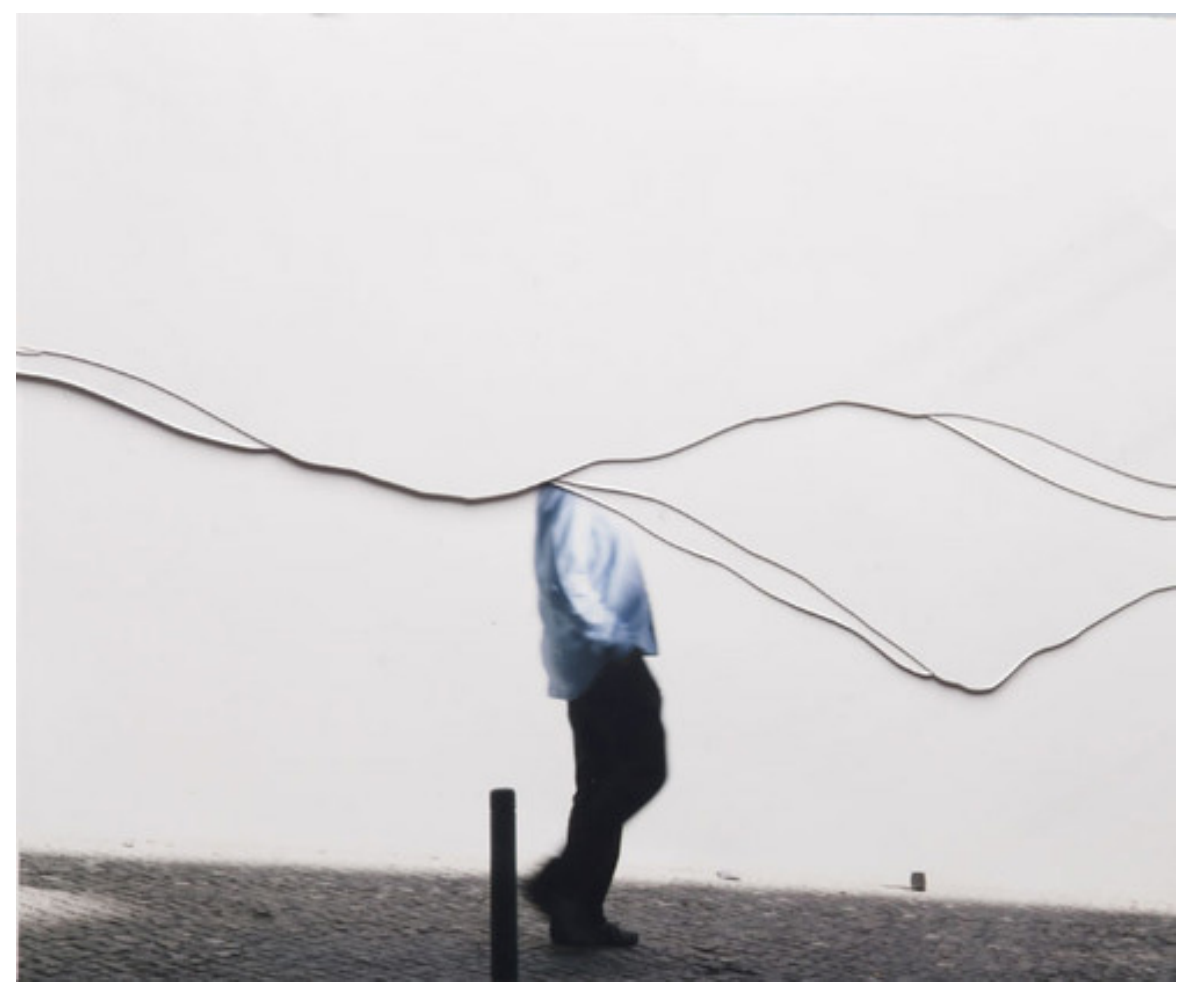

Fonte: reprodução imagem Julia Kater

Sob este eixo temático, o peculiar, para nós, será adentrar tal território da fotografia artística que trabalha na ausência do ver. Em outras palavras, pode-se inferir que, se existe uma gama de relações 


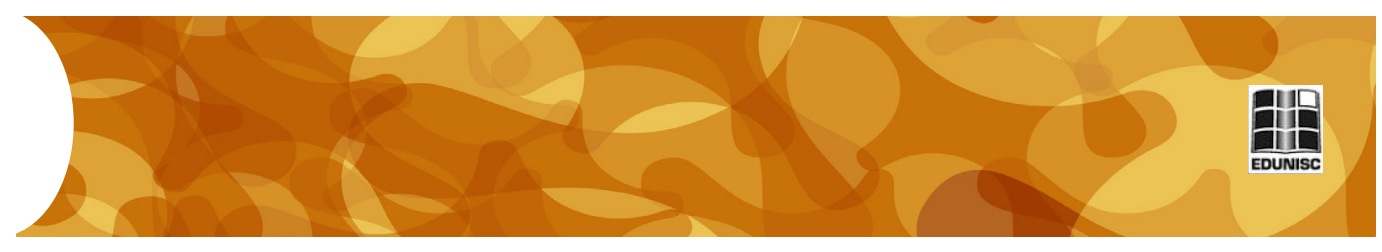

histórico-sociais e técnicas configuradas para ordenar o fotográfico como ferramenta que constata visíveis; como se dá esta possibilidade de pensar o significado das imagens pelo cruzamento entre o "ver" e "não-ver"?

\section{Filosofia e estética em Merleau-Ponty: a contiguidade do "ver" e do "não-ver".}

Em sua última obra inacabada, Merleau-Ponty (1984) irá justamente ultrapassar as oposições entre visível e invisível da estética, abrindo um paradigma filosófico que se põe além das noções clássicas de corpo e consciência; percepção e significado, que dominaram o pensamento científico e filosófico da primeira metade do século XX.

De um lado, a doutrina realista e naturalista, representadas pelos estudos biológicos e neurológicos da fisiologia e da psicologia behaviorista, que buscavam analisar o comportamento do indivíduo lidando somente com o mundo exterior - visto que o subjetivo seria impossível de ser estudado pela ciência; do outro, o idealismo que tem suas origens modernas a partir da filosofia de Descartes até Kant e Hegel. Apesar da influência heterogênea de cada pensador, de modo geral, tal filosofia considera que a inteligibilidade do conhecimento não se dá numa realidade fora do sujeito, mas é redutível aos termos que caracterizam a subjetividade humana sob os ditames da razão.

Ou seja, se o realismo busca entender o mundo natural como um todo separado do mundo interno (subjetividade), o idealismo não pode entender a vida como algo exterior à consciência humana. Em outras palavras, ambas as atitudes encerram uma negatividade no cognoscível que ora reside no mundo material, ora reside no sujeito, transformando a força negativa numa "essência", necessariamente oposta ao regime de saber postulado como positivo, verdadeiro.

Vale dizer que o que simplesmente não é, ou é pura negação, passa a dar expressão àquilo que, a rigor, "não tem nome, nem repouso ou natureza" (MERLEAU-PONTY, 1984, p. 90) diante de um regime de verdade. Consequentemente, o pensador defende que, para restituir ao mundo seu devido sentido, seria preciso libertá-lo da definição filosófica que trata o conceito de verdade sob uma relação oposta entre "tudo" e "nada", "existência" e "não-existência", "ver" e "não-ver", "ser" e "não-ser".

Para tanto, visto a construção histórica, ideológica social dos modos de ver, em Merleau-Ponty (1984), algo tomado como verdadeiro não tem por oposto necessariamente o falso; o improvável, o inexistente; o invisível. Segue-se, portanto, uma 


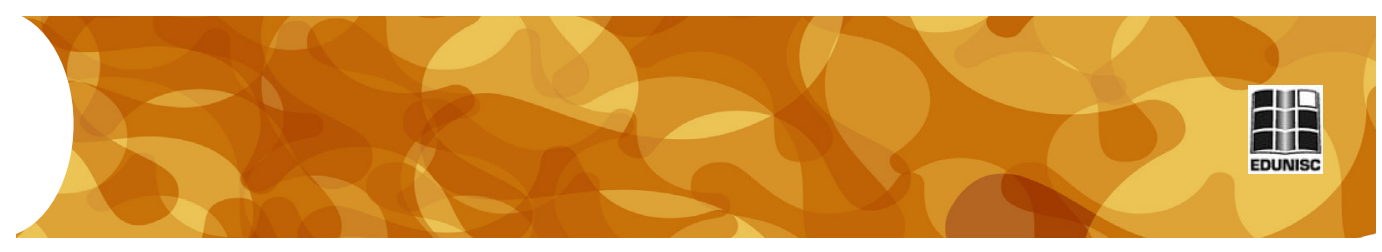

questão ontológica capaz de reconhecer o nada como relativo ao ser, visto que quando se afirma, diante de si, a existência do negativo, este naturalmente se destrói e é conduzido à positividade. Como explica Moutinho (2004, s/p):

\begin{abstract}
Se o negativo nada quer dizer, o positivo sozinho também nada diz, e no fim das contas os dois mostram-se sinônimos: dá no mesmo dizer que o nada não é e que há apenas ser. Pensar cada um dos opostos como a ausência ou a impossibilidade do outro redunda em compreendê-los como idênticos, e o único meio de sair deste impasse criado pelo entendimento será aceitar que o ser e sua negação não constituem instâncias alternativas nem contraditórias. Nessa perspectiva, princípios tais como "o ser é e o nada não é" ou "há tão somente ser", que o entendimento considera irredutíveis, revelam-se na realidade fórmulas derivadas de uma ordem prévia e unívoca de verdade, calcada no imperativo da identidade que obriga os opostos a repelirem-se mutuamente e jamais se interpenetrarem.
\end{abstract}

Não seria o caso de um elogio à negatividade como postula Sartre (1969), que pensa a necessidade do indivíduo negar a si mesmo para atingir a pura presença. Isto é, o encontro com a subjetividade absoluta na medida que o ser se desvencilha das amarras do "pensamento", do “ego", da "representação" e da "imagem". Pelo contrário, em MerleauPonty (1984), a nulidade é, por si só, constitutiva de ser, pois ao negarse o sujeito se lança em tal positividade, com a qual se identifica.

No tocante das aparências, a ocultação seria, por sua vez, uma dimensão que se apresenta latente ao campo dos visíveis. Em outras palavras, esta filosofia encara a representação do real habitada também pela negação em sua infraestrutura, combatendo justamente teorias que exploram a ideia de verdade como algo que recobre somente o campo dos visíveis.

E se, por um lado, a fotografia ainda é exaltada por retratar a verdade relativa ao ver, em consonância com o pensamento de Merleau-Ponty, as imagens de Kater parecem traçar esta negatividade visual capaz de gerar significados. O que está oculto na obra de Kater aparece, portanto, como a condição de possibilidade da imagem fotográfica. Uma performance do olhar que torna "visível" e "invisível" indissociáveis, posto que tal confronto visual - a negociação entre o "ver" e o "não-ver" - é o que dá potência às imagens (Figura 4). 


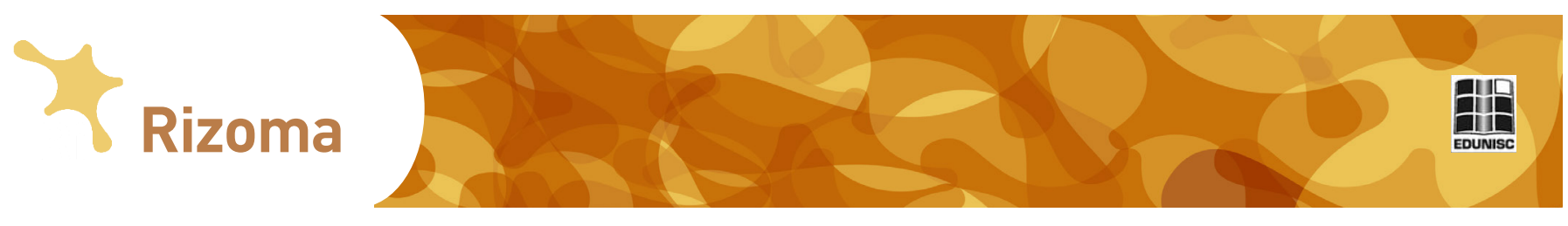

Figura 4 - Obra presente na exposição: Julia Kater - Como se fosse

(Caixa Cultural Brasília, 2014)
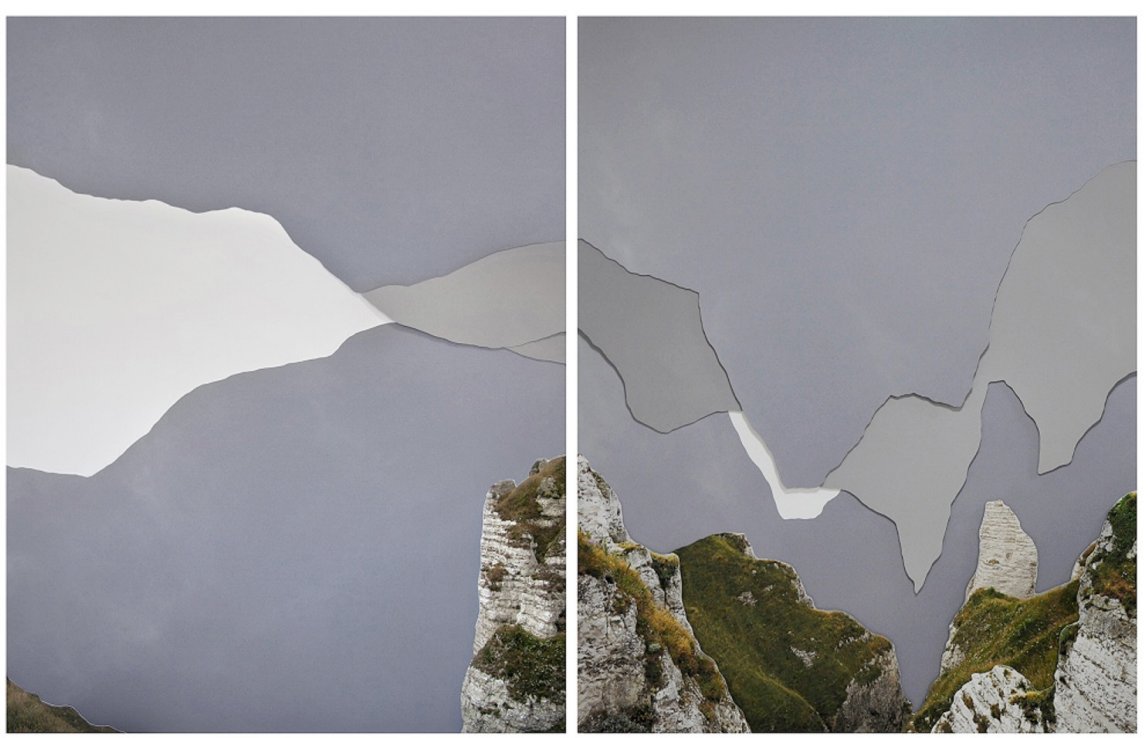

Fonte: reprodução imagem Julia Kater

Notadamente, Kater retrabalha o efeito visual de suas fotografias através de recortes e sobreposições. A artista irá adicionar elementos ao quadro fotográfico (a exemplo da série retratada na Figura 5), sobrecarregando a imagem até o total desaparecimento da mesma. Kater fará de sua obra a documentação deste processo de fatura, onde a relação inclusão/exclusão do "ver" se apresenta como mote da questão artística.

Figura 5 - Não disse com palavras, da série Silêncio, 2010. Políptico (4 fotografias $90 \times 60 \mathrm{~cm}$ cada).

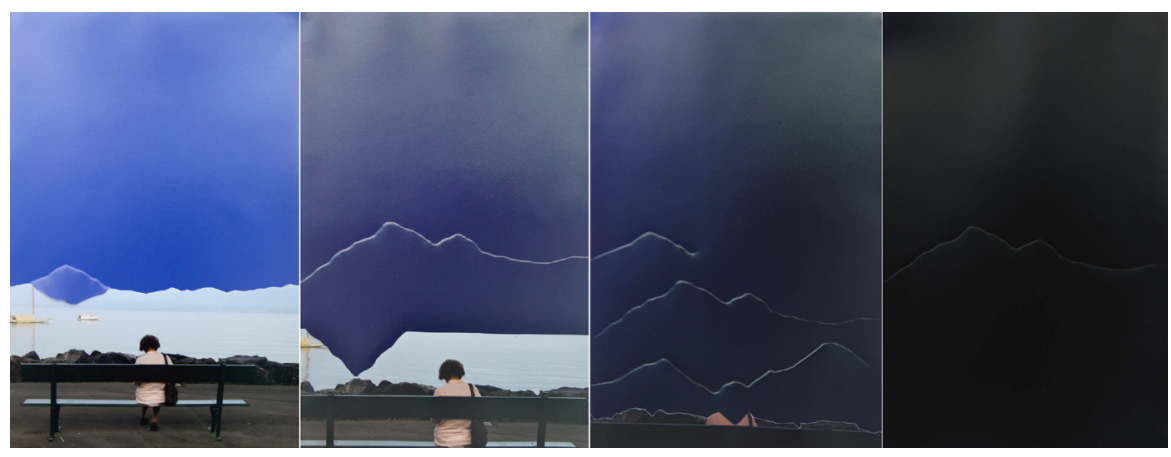

Fonte: reprodução imagem Julia Kater

Não por acaso, no ensaio "O olho e o espírito" (2004), os paradoxos da visão que animam a expressão da arte foram tema em Merleau-Ponty, que equiparou o processo de criação da imagem, na pintura, a uma autêntica ontologia. Nas palavras de Martins (2010, p. 479): 


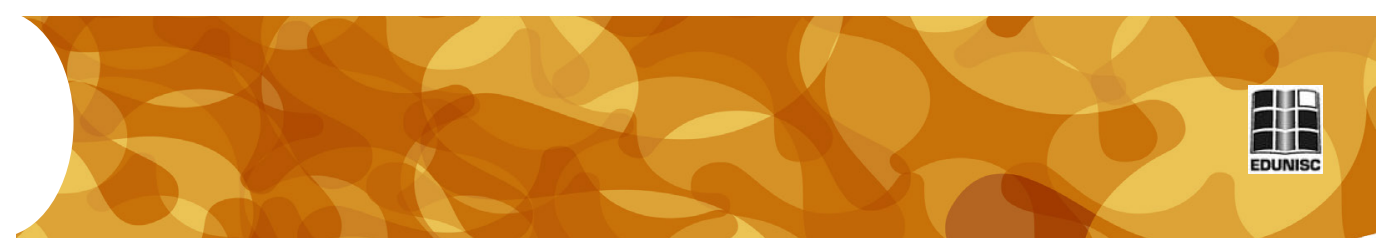

Para começar, a experiência pictórica é a prova por excelência de que a visibilidade "comporta" a invisibilidade - não como outra visibilidade possível, ou como um possível visível para outro, quer dizer, não como um objeto não visto, positividade situada alhures, mas como outra dimensão, em uma palavra, negatividade. Não a negatividade lógica ou contraditória, bem entendido, mas a negatividade como verticalidade e profundidade do visível: meio que as coisas possuem de permanecer nítidas para, "embora não como aquilo que olho atualmente", fazeremse coisas (MERLEAU-PONTY, 1984, p. 203). O maior enigma do pintor é exatamente esse invisível que medeia e liga as coisas, é neste âmbito que ele intenciona flagrar a própria estrutura da visão: sua experiência leva à última potência a espécie de "delírio" em que a própria visão em geral consiste - afinal, ver é um estranho "ter à distância".

A criação do pintor consiste, portanto, em pôr-se estranho ao ver, questionando a proximidade que construímos com as coisas visíveis e a consequente relação de distância que operamos com o que não se vê. Isto é, diante das limitações de nosso olhar, a aptidão do pintor estaria em tensionar a "cegueira da visão" para ampliar tal forma de visibilidade - sintoma de um elo indivisível entre "visível" e "invisível". Uma tentativa de jogar com as "formas do ver", o que nos faz entender a pintura não como obra exclusiva do seu criador, mas como fruto de uma relação ampliada entre o "sujeito que vê e cria" e "a coisa percebida".

A partir daí, Merleau-Ponty (2004) também irá refletir sobre a dimensão material da visão, pois "o ato de pintar" depende de um corpo que se apreende como visível, e operacionaliza seu olhar no meio das coisas (cena retratada pela pintura) e dos materiais utilizados para criação (pincel, papéis, telas, tintas). Trata-se de uma criação visual que conecta as possibilidades corporais do pintor junto àquelas delineadas pela técnica e pela matéria de criação. Nas palavras do filósofo,

Como todo vidente, o pintor está imerso no mundo por um corpo que é ele mesmo visível, mas não enquanto "porção" do espaço; sua visão depende do movimento desse corpo, razão pela qual o olhar do pintor jamais se "apropria" do visível, apenas dele se aproxima. Por ter ele mesmo um corpo, o pintor não pode eximir-se de sua própria visibilidade para os outros - daí tantos pintores terem dito que "as coisas os olham" em vez de serem olhadas por eles. (MERLEAU-PONTY, 2004, p. 22).

Como um efeito que cruza visível e tangível, em Merleau-Ponty, pensar a questão da visibilidade é, então, dar conta do corpo como meio - dada a sua capacidade material de conectar o sujeito aos fenômenos do mundo. Por sua vez, aqui, a estética passa a ser compreendida não como um registro de critérios visuais, sob obras categorizadas por vanguarda, estilo ou artista, mas pelas condições corporais-materiais que ordenam tal produção de subjetividade. Uma teoria visual atenta à corporificação na produção de sentido na arte, que nos permite abrir um diálogo entre estética, corpo e comunicação. Contudo, neste filósofo, a 
pintura se mostra como o encontro intrínseco desta conexão entre corpo e visível, onde as pinceladas do pintor são compreendidas como um ato de negociação entre corporeidade e visibilidade. Resta-nos, então, ampliar a teoria estética de Merleau-Ponty para os usos e funções de outras mídias, como a fotografia. Ou seja, dado o corpo como primeira instância que constrói as existências visuais; como o sujeito, junto à materialidade da técnica fotográfica, age para comunicar e retratar este jogo contraditório da visão - que complementa "visível" e "invisível"?

Justamente como sugere Merleau-Ponty na pintura, a arte fotográfica de Julia Kater cria um jogo de aparição e de ocultamento diante da obra, a fim de questionar as formas de uso da técnica fotográfica e a produção de sentido das imagens. Seria papel do pesquisador, enveredar por uma via fenomenológica e esmiuçar as relações corpo-visão estabelecidas por Kater no processo de fatura destas obras. Mas, neste trabalho inicial, viso apenas a delinear os pressupostos teóricos que buscam assegurar este tipo de análise.

Kater faz de seus registros fotográficos um trabalho em aberto. Ela age nas imagens fotográficas, recortando e colando pedaços de papel quase sempre de mesma cor, mas em tons variados, sobre a fotografia. Há um desejo de manufatura em suas fotos, que visa a burlar o efeito realista da técnica fotográfica, e relembra fortemente as práticas pictorialistas do século $\mathrm{XIX}^{2}$, ou as práticas de fotomontagem de inspiração dada e surrealista do século $\mathrm{XX}^{3}$.

É este favorecimento de uma prática manual - do recorte e "do tirar e pôr sobre a imagem" - que cria uma leitura diferenciada de suas fotografias. A tal ponto que a apreensão das imagens fotográficas, exibidas por Kater, irão convocar a ação do espectador que se vê impelido a subtrair ou a preencher visualmente aquilo que se apresenta na obra. A imagem, com isso, se torna uma experiência por vir que depende do jogo de adição e de subtração visual criado pelo espectador, e por sua capacidade de exercitar uma profundidade no olhar ${ }^{4}$.

\section{Considerações Finais:}

Ao longo da História, a imagem reafirmou seu caráter documental e artístico sob os critérios estilísticos que prezavam pelo efeito-real da mimese. Mas por que a visão - em sua função de apresentar signos - agora passa a querer escondê-los? Quais seriam as razões para a fotografia artística negar o território do visível? E qual o papel das novas tecnologias diante da proeminência do bloqueio do ver na arte contemporânea?

Ao fazer do invisível condição de visibilidade, os ocultamentos da obra de Julia Kater nos abrem justamente para tais questões,
2 Tomando como referência os padrões estilísticos da arte pictórica paisagem, retrato, natureza morta $-\mathrm{o}$ movimento pictorialista investia no caráter subjetivo da fotografia ao inserir, literalmente, a mão do artista no filme. Ou seja, para negar a exatidão e a nitidez do processo técnico, os pictorialistas forjavam uma arte fotográfica ao manipular o negativo através de pincéis, lápis, além de outras técnicas e processos químicos. Este movimento desenvolveu a busca pela plasticidade experimental da imagem, modificando os rumos dos usos da fotografia de sua época. Frank Eugene, Constant Puyo,

Robert Demarchy e Heinrich Kuhn eram alguns de seus expoentes. São fotógrafos que buscavam inspiração na pintura, olhando "tanto para artistas individuais (Diego Velázquez, Eugene Delacroix, Constable, Rosseau, Corot,

Millet, Bastien-Lepage, Whistler, Arnold Bocklin, Monet) quanto para alguns movimentos contemporâneos

(pré-rafaelismo, impressionismo, tonalismo e simbolismo). (FABRIS,

2011, p. 42).

${ }^{3}$ A collage pictórica, "que surge como forma artística desde o período da Primeira Guerra Mundial" (GONZÁLEZ FLORES, 2011, p. 186), e a fotomontagem no dadaísmo e no surrealismo são procedimentos artísticos que encontram seus fundamentos, e que justificam sua atividade, mediante $\mathrm{o}$ ato de selecionar e de recombinar materiais pré-existentes. As fotomontagens do

início do século XX, por exemplo, desenvolveram um gesto artístico paralelo ao ready-made de Duchamp. John Heartfield, Raoul Hausmann, Hannah Höch, Max Ernst, Moholy-Nagy, Kurt Schwitters, George Grosz - inspirados pelas vanguardas dada e surrealista criam jogos de associação simbólica por meio da reciclagem de fotografias

(DUBOIS, 2011). Uma estratégia que preza pelo reuso de fragmentos fotográficos, onde o simples ato de escolher - "de retirar de um lugar e colocar em outro" - basta para justificar a atividade artística.

\footnotetext{
4 "As imagens da arte - por mais simples e "mínimas" que sejam sabem apresentar a dialética visual desse jogo no qual soubemos (mas
} 


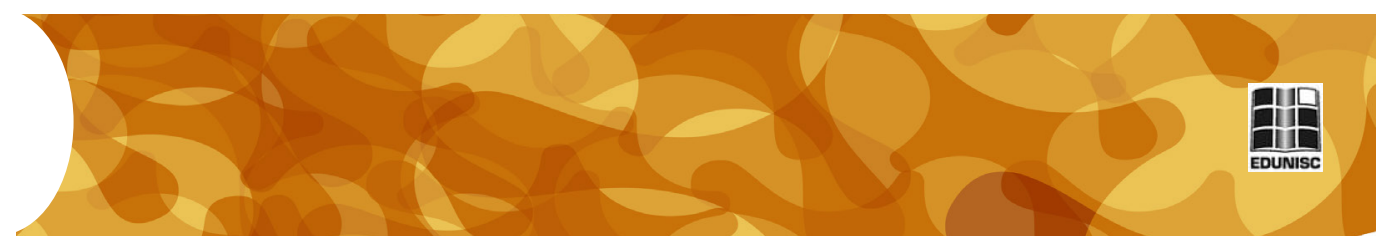

tão caras para esta pesquisa. São imagens que extrapolam noções clássicas que definem o meio fotográfico sob a égide da representação mimética, ao passo que evidenciam uma produção de sentido dado pelo encontro conflituoso entre "ver" e "não-ver". Em outras palavras, as lacunas visuais da obra de Kater são capazes de abrir a imagem fotográfica para sua condição arbitrária e ambígua, bem como para este múltiplo território de negociação visual que constitui nossas formas de perceber.

Ao revés da busca pela unidade de sentido, as falhas das fotografias de Julia Kater mobilizam certa instabilidade ao olhar. Trata-se de uma força visual que advém dos efeitos dados pela omissão de sentido - que provocam o questionamento dos estereótipos, e das referências histórico-temporais e espaciais da fotografia de cunho documental. Para tanto, devemos estar atentos a produções artísticas que esgotam a presença imediata do que é dado a ver, e que desorganizam as concepções clássicas de fruição da imagem.

Nestes termos, a visão filosófica de Merleau-Ponty identifica, para além de modelos epistemológicos do classicismo, uma criação visual que incorpora o "não-ver" à produção de imagens da arte. O ocultamento aparece, portanto, como face inerente às possibilidades de sentido da narrativa imagética.

\section{Referências}

DIDI-HUBERMAN, Georges. O que vemos, o que nos olha. São Paulo: Ed. 34, 2010.

DUBOIS, Philippe. O Ato fotográfico. Campinas: Papirus, 2011.

FABRIS, Annateresa. O desafio do olhar: fotografia e artes visuais no período das vanguardas históricas. São Paulo: Martins Fontes, 2011.

GONZÁleZ FlORES, Laura. Fotografia e Pintura. Dois meios diferentes? São Paulo: Martins Fontes, 2011.

MARTINS, Paula Mousinho. Entre visível e invisível, para além do entendimento: o tema da natureza no último Merleau-Ponty. Aurora, Curitiba, v. 22, n. 31, p. 469-482, jul./dez. 2010.

MERLEAU-PONTY, Maurice. O visível e o invisível. São Paulo: Perspectiva, 1984. esquecemos de) inquietar nossa visão e inventar lugares para essa inquietude" (DIDI-HUBERMAN, 2010, p. 97). 


\section{Rizoma}

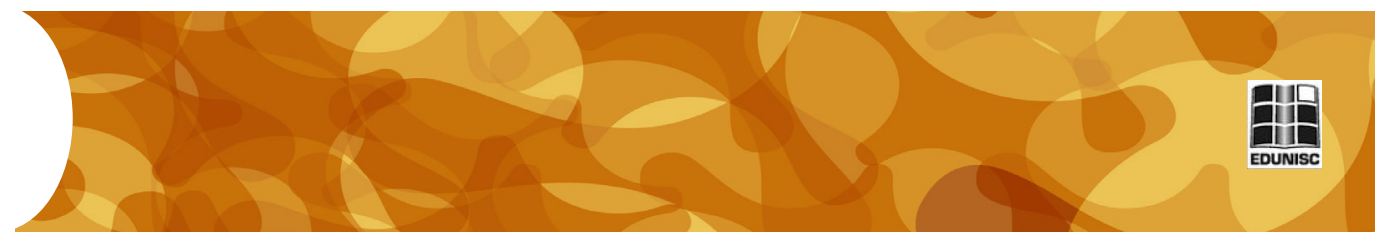

MERLEAU-PONTY, Maurice. O olho e o espírito. São Paulo: Cosac \& Naify, 2004.

MOUTINHO, Luiz Damon Santos. O invisível como negativo do visível: a grandeza negativa em Merleau-Ponty. Trans/Form/Ação, Marília, v. 27, n.1, 2004.

SARTRE, Jean-Paul. L'être et le néant. Paris: Gallimard, 1969.

SIMONDON, Gilbert. Du mode d'existence des objets techniques.

Paris: Aubier, 1958. 